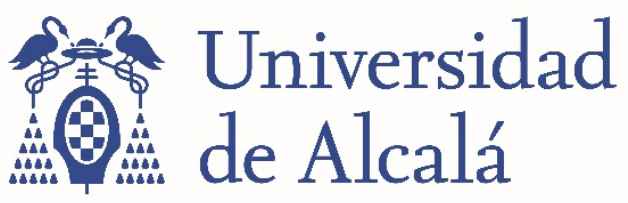

BIBLIOTECA

Document downloaded from the institutional repository of the University of Alcala: http://dspace.uah.es/dspace/

This is a postprint version of the following published document:

Sánchez-Colomer, M.G. \& Escudero, A. 2004, "Landscape- and Field-Scale Control of Spatial Variation of Soil Properties in Mediterranean Montane Meadows", Biogeochemistry, vol. 69, no. 2, pp. 207-225.

Available at http://dx.doi.org/10.1023/B:BIOG.0000031047.12083.d4

(C) 2004 Kluwer Academic Publishers
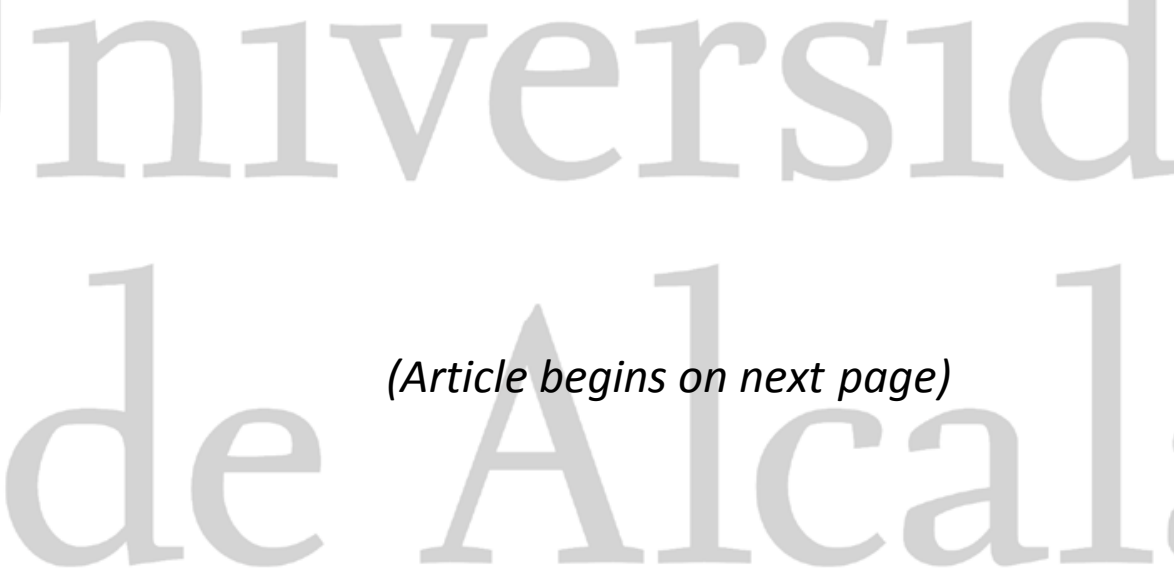

(Article begins on next page)

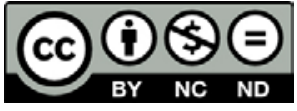

This work is licensed under a

Creative Commons Attribution-NonCommercial-NoDerivatives

4.0 International License. 
Running title: Modeling control of soil properties

Article type: general research

\section{Landscape- and Field-Scale Control of Spatial Variation of Soil Properties in Mediterranean Montane Meadows}

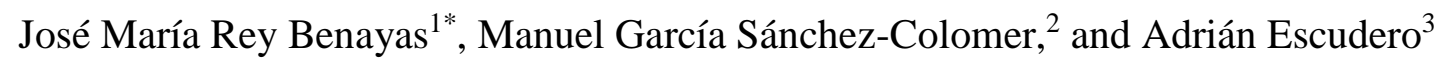

* Corresponding author

${ }^{1}$ Departamento. de Ecología, Edificio de Ciencias, Universidad de Alcalá, 28871 Alcalá de Henares, Spain; Tel. +34 91 8854987, Fax +34 91 8854929, e-mail josem.rey@uah.es

${ }^{2}$ CEDEX, MOPTMA. P. Bajo de la Virgen del Puerto, 3, E-28005 Madrid, Spain

${ }^{3}$ Área de Biodiversidad y Conservación, ESCET Universidad Rey Juan Carlos, E-28933

Móstoles, Spain 


\section{ABSTRACT}

Soil properties of terrestrial ecosystems are controlled by a variety of factors that operate at different scales. We tested the role of abiotic and biotic factors that potentially influence spatial gradients of total ion content, acidity, carbon, total nitrogen, and total phosphorous in topsoil. We studied a network of Mediterranean montane meadows that spans a 2000-m altitudinal gradient. The analyzed factors were grouped into two spatial scales: a landscape scale (climate and land form) and a field scale (topography, soil texture, soil moisture, and plant community composition). Total ion content and acidity are the major and independent variation trends of soil geochemistry. Soil acidity, carbon, and nitrogen increased along the altitudinal gradient whereas there was no relationship between total ion content and phosphorous and elevation. Climate had not a direct influence on the analyzed gradients; all effects of climate were indirect through plant community composition and/or soil moisture. The results point to three types of models that explain the gradients of soil chemical composition: (1) a predominantly biotic control of carbon and nitrogen, (2) a predominantly abiotic control of acidity, and (3) a combined biotic and abiotic control of total ionic content. No direct nor indirect effects explained the gradient of phosphorous. In our study region (central Spain), climate is predicted to turn more arid and soils will lose moisture. According to our models, this will result in less acid and fertile soils, and any change in plant community composition will modify gradients of soil carbon, nitrogen, total ion content, and acidity.

Key words: acidity; carbon; Mediterranean plant communities; nitrogen; spatial scale; total ion content. 


\section{INTRODUCTION}

Soil properties of terrestrial ecosystems are controlled by a variety of factors that operate at different spatial and temporal scales. Climatic factors such as precipitation and temperature, land form, topography, and complex interactions among physical, chemical, and biological processes play a key role in configuring soil properties (Davidson 1995; Groffman et al. 1996; Goderya 1998; Sinowski \& Auerswald 1999; Johnson et al. 2000). The relative importance of these factors are scale-dependent. For instance, variation in climate and geomorphology manifest themselves primarily at landscape scales. However, a relatively small land form unit (e.g., a bottom valley) may include different topographic features as well as a mosaic of soil patches of different texture, moisture, and chemical composition (Grigal et al. 1991;

Goovaerts \& Chiang 1993; Kumar et al. 1996; Crawford \& Hergert 1997; Fitzjohn et al. 1998; Strong et al. 1998; Giesler et al. 1998; Burke et al. 1999; Vervoort et al. 1999; Wendroth et al. 1999; Burke 2000). These sources of spatial variation are particularly relevant in mountainous regions where strong environmental gradients appear (Barry 1990). Thus, altitude reproduces at landscape scales some gradients and patterns that mirror latitudinal variation. Temporal variability such as daily to seasonal changes in soil water content and temperature are also important factors and affect processes such as $\mathrm{C}$ and $\mathrm{N}$ mineralization and decalcification (Sival \& Grootjans 1996; Butterworth et al. 1999a and 1999b; Gilmanov et al. 1997).

This paper primarily focuses on the understanding of the spatial variation of soil properties in the meadow network of a Mediterranean montane landscape. This understanding is important because the effects of soils on ecological processes are of broad interest, especially with regard to the effects of global change (IPCC 1995). Most of the habitats studied match the definition of wetlands (Rey Benayas et al. 1998). The relevance of wetland habitats is most prominent in dry climate areas such as the Mediterranean regions of the 
world, where very often they are totally or partially fed by shallow water tables and groundwater outcropping.

\section{Objectives and Hypotheses}

We described the spatial variation of topsoil properties to address two major questions: 1) what are the factors controlling the gradients of soil chemical composition?, and 2) are they differentially operating at different spatial scales? We depart from a priori modeling approach that can be used in other ecosystem types elsewhere in the world as a tool for understanding spatial variation of soil properties. We tested the role of various environmental factors that can potentially influence the gradients of total ion content, acidity, carbon, total nitrogen, and total phosphorous content. We hypothesized that these gradients depend on the complex interaction of a set of biotic and abiotic factors that are relevant at two different spatial scales (Figure 1): (1) a landscape scale (climate and land form) and (2) a field scale (topography, soil texture, soil moisture, and plant community composition). We hypothesized the following:

Topography is affected by (1) climate and (2) land form. Run-off highly contributes to shape topographic patterns (Fitzjohn et al. 1998). Additionally, climate affects two other field scale control factors: (3) plant community composition and (4) soil moisture (Harte et al. 1995; Athavale et al. 1998; Butterworth et al. 1999a). We hypothesized that climate directly affects (5) gradients of soil chemical composition, e.g. by affecting decomposition rates of organic matter (Gilmanov et al. 1997; Updegraff et al. 1995; Boix-Fayos et al. 1998) and base-cation export (Van Breemen et al. 1983).

Soil texture is affected by (6) land form and (7) topography (Blank et al. 1995; Lev \& King 1999; Sinowski \& Auerswald 1999). (8) Topography and (9) soil texture affect soil moisture (Bouten \& Witter 1992; Groffman et al. 1996; Athavale et al. 1998; Fitzjohn et al. 
1998; Moustafa-Mahmoud \& Yomota 1998; Yeakley et al. 1998). Thus, steeper slopes provide drainage that favors loss of soil water, but they may also contribute to outcropping of groundwater that would result in moist soils. Additionally, (10) soil texture directly affects gradients of soil chemical composition (Kumar et al. 1996). A sandy texture contributes to soil aeration and, subsequently, may favor higher decomposition of organic matter (Updegraff et al. 1995), whereas prevalence of finer clay texture elements may avoid leaching of nutrient cations which necessarily need to be attracted to stable soil particles.

Soil moisture affects (11) plant community composition because water is a major resource and a condition for plants (Weisberg \& Baker 1995; Meinzer et al. 1999; Jarolimek et al. 2000). Gradients of soil chemical composition are directly affected by (12) soil moisture. For instance, water logging creates hypoxic environments that partially impedes the mineralization of organic matter, particularly if temperature is cold, and patterns of soil moisture status highly affect the heterogeneity of soil water and solute transport and leaching of chemicals (Vervoort et al. 1999; Wendroth et al. 1999). Finally, we hypothesized that (13) plant community composition directly affects gradients of soil chemical composition. Plants importantly affect nutrient cycles through the amount of biomass they yield to soils, decomposition rates, deciduous or evergreen leaves, and N-fixing properties (Roy 1996; Blackstock et al. 1998; Steltzer \& Bowman 1998; Stottlemyer \& Troendle 1999; Gao et al. 1996). There are virtually thousands of studies in the scientific literature that have looked at how soil chemical composition affects plant community composition, whereas the opposite direction -our link- has received little attention by ecologists and pedologists (Callaway 1995 and 1997). 


\section{MATERIAL AND METHODS}

\section{The Empirical Data}

We studied a network of meadows located in the Sierra de Guadarrama mountain range (central Spain). Mid coordinates of the study area are $40^{\circ} 45^{\prime} \mathrm{N}$ and $3^{\circ} 55^{\prime} \mathrm{W}$. It encompasses $2069 \mathrm{~km}^{2}$. Elevation ranged between 560 and 2,430 m a.s.l. The parent material of the study area is impermeable granitic rocks. In this landscape type, over 95\% of water flow is surface and subsurface flow and groundwater flows through the rock fractures spread over the mountain range. The climate is Mediterranean and highly seasonal. However, groundwater seepage locally mitigates the effects of summer drought. Mean annual temperature among sites ranges from 12.4 and $6.3^{\circ} \mathrm{C}$, and total annual precipitation varies between 456 to 1,331 $\mathrm{mm}$, at the lowest and highest elevations. Elevation leads to a progressive decrease in potential evapotranspiration and a peak of ca. $520 \mathrm{~mm}$ of actual evapotranspiration at mid elevation (1,300-1,500 m). Soils range between cambisols and arenosols in lower zones to ranker in the summit areas.

\section{Meadow mapping and landscape features}

We sampled 92 10x10-m² plots for soil and plant communities in 66 meadow habitats. Plot locations were chosen to maximize the environmental range sampled, particularly elevation and soil moisture. Most of the meadows (66.7\%) had 1 plot with a maximum of 4 plots in one meadow. For small meadows with only one obvious habitat zone, the plot was placed in the center. For larger meadows, plots were centered in each conspicuous habitat belt. The plots cover a complete range of communities, relatively dry pastures related to ephemeral vernal 
pools, wet meadows, meadows that punctuate forests dominated by Fraxinus angustifolia, Quercus pyrenaica or Pinus sylvestris and alpine shrubland dominated by Juniperus communis. Prior to field surveys, we used panchromatic aerial photographs to map this variety of habitats in the study area. The meadows are usually small in size, ranging from 100 $\mathrm{m}^{2}$ to $34,572 \mathrm{~m}^{2}$ (mean $\pm \mathrm{SD}$ is $3,189 \pm 6,547 \mathrm{~m}^{2}$ for our sampled sites). We selected recent, 1:20000 scale photographs taken in the summer of 1999 to generate an updated, accurate map of the meadow zones. The photo-interpretation results were scanned to produce a digitized map.

Since parent material is very homogenous across the analyzed soils, landscape scale approached two types of features: climate and land form type. In the interest of simplicity, our models include a single climate measure, the Thornwaite's (1948) water index (TWI). This index represents a balance of climatic water availability to plants. In the area, the TWI increases with increasing elevation up to ca $1700 \mathrm{~m}$, then it does not change; correlation between TWI and elevation was highly significant (Figure 2A). We used 1:50000 geological and geomorphologic maps and our photo-interpretation to ascertain the land forms corresponding to the meadows that we sampled in the field. These maps distinguish three major morphotectonic units (ridge, marginal ridge, and piedmont) and five major geomorphologic units (slope, flat highland, secondary valley, structural basin bottom, and piedmont).

\section{Field features}

In our conceptual framework, field scale included characterization and measures related to topography, soil texture, moisture and chemical composition features, and plant community composition. We used three types of variables related to topography, namely topographic 
position, drainage and slope. We distinguished three major topographic positions (uphill, hillside, and bottom slope) and three major drainage categories (drained or exoreic soils, flat endoreic soils, and concave endoreic soils). Slope was field-measured by means of a clinometer. All three types of topographic variables were highly related. Again in the interest of simplicity, we used the topographic slope in our models to synthesize topographic features. Correlation between topographic slope and elevation was positive (Figure 2B).

In every plot, we took five 20 -cm depth soil cores from the square center and from the center of their four quadrants. Every individual soil sample was examined in situ for water saturation and gley signs. Based upon these field soil indicators, we came up with seven hygrotypes that were ranked from 1 (the driest soil type) to 7 (flooded soils). The use of hygrotypes has been proved to be a satisfactory measure of soil water content (Rey Benayas 1995; Wang \& Klinka 1996; Rey Benayas et al. 1998). An average hygrotype of the 5 soil samples was then calculated for every plot (Table 1). Despite the positive correlation between soil moisture and elevation, the examination of the graph (Figure 2C) reveals always dry soils at low elevations (below $900 \mathrm{~m}$ ), very wet or flooded soils at high elevations (above $1500 \mathrm{~m}$ ), and a great variability of soil moisture at intermediate elevations.

The five soil samples taken in each plot were merged into one to reduce sample heterogeneity. In the laboratory, the composite samples were analyzed for texture and chemical composition. Texture analysis followed the Boyoucos (1935) method (Table 1). Organic matter, Kjeldahl N (organic N plus ammonium) and total phosphorous were directly analyzed in soil samples. For phosphorous we used Bray's method for acid soils: 1 soil g was extracted with a $7 \mathrm{ml}$ solution consisting in $15 \mathrm{ml}$ of $\mathrm{NH}_{4} \mathrm{~F}+100 \mathrm{ml}$ of $\mathrm{HCl}+385 \mathrm{ml}$ of distilled water; the extract was analyzed with a TECNICOM AA2. Aqueous extracts of the dried soil samples (1:10 weight : volume) were prepared and the filtered solution was analyzed for $\mathrm{pH}\left(\right.$ at $20^{\circ} \mathrm{C}$ ), electrical conductivity (at $\left.25^{\circ} \mathrm{C}\right), \mathrm{NO}_{3}{ }^{-}$and major ions $\left(\mathrm{Na}^{+}, \mathrm{K}^{+}\right.$, 
$\mathrm{Ca}^{2+}, \mathrm{Mg}^{2+}, \mathrm{SO}_{4}{ }^{2-}, \mathrm{Cl}^{-}$, and $\left.\mathrm{CO}_{3} \mathrm{H}^{-}\right)$. Aqueous extracts usually results in low ion

concentrations, and plants can extract more than that from soil. However, with this method we will be able to compare among-plot soil chemical composition within the study area and, additionally, with soil chemical composition in adjacent regions (Bernáldez \& Rey Benayas1992).

We also visually measured in the field the percentage cover of all perennial plant species in the plots (237 species in total). Annual species are extremely rare in these communities.

\section{Modeling}

To obtain a synthetic and quantitative land form variable, we constructed a presence-absence matrix of 92 plot-by-8 land form variables that was subjected to ordination by means of a Correspondence Analysis (CA) (Rey Benayas et al. 1999). The results provided a first axis that absorbed $37.1 \%$ of the total inertia and that was easily interpreted as a gradient of exportation (source) versus importation (sink) of materials (Rey Benayas et al. 1999). This axis will be used as the land form variable in our models. The correlation between land form and elevation was $r=-0.73, \mathrm{P}<0.0001(\mathrm{n}=92)$.

We performed a Principal Component Analysis (PCA) on soil sand, silt, and clay proportions to obtain a synthetic variable of soil texture. The first component placed sand on one pole and clay in the other pole. We also found a positive correlation between sand proportion and elevation (Figure 2D) and a negative correlation between clay proportion and elevation ( $r=-0.46, \mathrm{p}<0.0001, \mathrm{n}=82)$.

The plant species-by-plot matrix (cover values) was ordinated by means of a CA to obtain a synthetic variable of plant community composition (García Sánchez-Colomer 1999). Our analysis detected seven outlier plots that spanned over $75 \%$ of the total length of the first axis. Thus, we repeated the ordination excluding these plots and the resulting first axis was used as 
a synthetic variable of plant community composition. The correlation between plant community composition and elevation was $0.85(\mathrm{p}<0.0001, \mathrm{n}=85)$.

Finally, we performed a PCA on soil $\mathrm{pH}$, electrical conductivity, $\mathrm{Na}^{+}, \mathrm{K}^{+}, \mathrm{Ca}^{2+}, \mathrm{Mg}^{2+}$, $\mathrm{SO}_{4}{ }^{2-}, \mathrm{Cl}^{-}$, and $\mathrm{CO}_{3} \mathrm{H}^{-}$contents in order to highlight the variation trends of soil chemical composition and to obtain synthetic variables that will be used in the explanatory models (see Results). We used the PC-ORD statistical package (McCune \& Mefford 1995) for all the ordinations.

Structural equation modeling (SEM) was used to investigate how well our empirical data supported hypothesized relationships among a set of variables. The advantages of SEM in path analysis are related to the possibility of testing the overall agreement between the path model and the data (Hayduk 1987; Loehlin 1987; Mitchell 1992). The hypothetical models describe how variables are linked in terms of direct and indirect effects. The model was evaluated separately for the following gradients: 1) total ion content, 2) acidity, 3) organic matter expressed as carbon, 4) total nitrogen, and 5) total phosphorous. We hypothesized that gradients of soil chemical composition depends on the complex interaction of a set of biotic and abiotic factors interacting at two different spatial scales. The model comprises six control factors, and thirteen direct and indirect effects (paths) (Figure 1).

The null hypothesis of the models is that the observed and predicted variances and covariances are equal, assuming that the empirical data were generated by the effects specified by the models (Shipley 1999). If the calculated probability under the null hypothesis is small (universally below $P<0.05$ ), then one must conclude that the null hypothesis is false, i.e. the observed data were unlikely to have been generated by the hypothetical factors. If the null model is not rejected, we have no good statistical reason to reject the hypothetical factors, and the model remains as a potential explanation. 
The maximum likelihood method was used to estimate standardized path coefficients. We tested for collinearity among predictor variables by calculating variation inflation factors (VIFs) for each variable (Petraitis et al. 1996). None of the variables was eliminated because their VIF values were below 10 (Chatterjee \& Price 1991). SEM allows assessment of the degree of fit between the observed and expected covariance structures, expressed as a goodness-of-fit $\chi^{2}$. A significant $\chi^{2}$ indicates that the model does not fit the data. However, a significant $\chi^{2}$ can also result from violation of several assumptions whereas failure to reject a model (a non-significant $\chi^{2}$ ) may result from inadequate statistical power (Bentler 1989; Mitchell 1993; Albert et al. 2001). In order to minimize this risk, we used the Bentler-Bonett Normed Fit Index (NFI), which is based on the model $\chi^{2}$ relative to that of a model that assumes independence of all variables. We followed the recommendations of Tanaka (1987) about the simultaneous use of the Goodness of Fit index (GFI) (Tanaka \& Huba 1985). Both indexes (NFI and GFI) range between 0 and 1, with values higher than 0.90 indicating a good fit (Bentler 1989).

Finally, multi-variate Wald tests were performed to assess the significance of individual path coefficients. The Wald test located the set of path coefficients that can be considered zero without worsening the fit of the model (Buse 1982; Bentler 1989). The unexplained variation $\left(U_{i}\right)$ of the dependent variables in the path models was estimated as $U i=\left(1-R_{i}{ }^{2}\right)^{1 / 2}$, where Ri is the squared multiple correlation (Mitchell 1993). Significance tests are possible only for direct effects. Some authors recommend the respecification of the model in an iterative process. The final objective is to achieve a simpler model (the parsimony criterion). We have not conducted this procedure because then data and not theory drive model building, and the analysis becomes just a numerical exercise (Petraitis et al. 1996). SEM analysis was performed with the CALIS procedure of the SAS Statistical Software package (SAS Institute 1990). 


\section{RESULTS}

\section{Spatial Variation of Soil Chemical Composition}

The PCA performed on soil chemical variables highlighted the major and independent variation trends of soil geochemistry (Table 2). The first component, accounting for $54.6 \%$ of the total variation, may be interpreted as total ion content, since electrical conductivity is the most relevant variable. The second component, accounting for $15.2 \%$ of the total variation, may be interpreted as soil acidity given the relative importance of $\mathrm{pH}$ and $\mathrm{CO}_{3} \mathrm{H}^{-}$in this linear combination. These two first principal components will be used as synthetic variables of soil chemical composition in the SEM models.

Regional trends evaluated as the relation between altitude and gradients of soil chemical composition showed contrasting results. There was no relationship between total ion content and elevation (Figure 3A). Soil acidity, carbon and nitrogen contents increased with elevation (Figures 3B, 3C and 3D, respectively). Phosphorous was found not to be correlated with elevation (Figure 3E).

Except for carbon and nitrogen $(\mathrm{r}=0.93, \mathrm{p}<0.0001, \mathrm{n}=91)$ and soil acidity and nitrogen ( $r=0.25, p<0.009, n=91)$, none pair-wise correlations between total ion content, acidity, carbon, nitrogen, and phosphorous were found to be significant after applying Bonferroni corrections for multiple comparisons.

\section{Hypothesis testing by Structural Equation Modeling}

Models for total ion content $\left(\chi^{2}=18.42, \mathrm{P}=0.012\right)$, acidity $\left(\chi^{2}=15.52, \mathrm{P}=0.3\right)$, and phosphorous concentration $\left(\chi^{2}=16.81 \mathrm{P}=0.018\right)$ had non-significant $\chi^{2}$ at $\mathrm{P}<0.01$ once Bonferroni corrections were applied. However, the models for carbon $\left(\chi^{2}=19.55, \mathrm{P}=0.007\right)$ 
and nitrogen $\left(\chi^{2}=19,26 \mathrm{P}=0.007\right)$ were significant at $\mathrm{P}<0.01$. We conducted the NFI and GFI to contrast these results. These indices indicate an excellent fit compared to a null model that assumes independence among all variables. GFIs and NFIs values are the following, respectively: 0.933 and 0.934 for total ion content, 0.942 and 0.942 for acidity, 0.931 and 0.939 for carbon, 0.932 and 0.938 for nitrogen, and 0.936 and 0.939 for phosphorous.

The relationships between the hypothesized control factors of gradients of soil chemical composition were very similar in all models (Figure 4). As expected, climate was a robust predictor of soil moisture and plant community composition, but contrary to our hypothesis it had no effect on topography. This lack of relationship is in disagreement with the pair-wise correlation between climate and topography (Table 3). In agreement with our hypotheses, land form strongly determines topography and soil texture. The signs of the path coefficients indicate that upper relieve positions favor steep slopes and coarse-textured soils, whereas lowlands are relatively flat and have fine-textured soils. Soil texture significantly affects soil moisture, coarse-textured soils being moister than fine-textured soils. We did not find any significant direct effect of topography on soil moisture and texture. In this case, pair-wise correlations are also significant (Table 3). Finally, we found an strong effect of soil moisture on plant community composition.

In order to compare the models, we considered direct and indirect effects on gradients of soil chemical composition. Climate did not have any direct effect on these gradients (Figure 4). This lack of relationships is mediated by an indirect effect in the case of carbon and nitrogen contents ( $\mathrm{r}=0.44$ and 0.46 , respectively, $\mathrm{p}<0.0001, \mathrm{n}=91$ ). The pair-wise correlations between climate and total ion content, acidity, and phosphorous concentration were not significant ( $\mathrm{P}>0.3$ in all three cases).

The results of SEM highlight the existence of three contrasting types of models for gradients of soil chemical composition. The gradient of total ion content is simultaneously 
and directly controlled by both biotic (plant community composition) and abiotic (soil moisture, with a positive effect) features. There is also an important indirect and negative effect of soil texture (path coefficient is -0.295) (Figure 4A). Soil acidity is directly related to soil moisture and texture but no effect related to plant community composition appeared (Figure 4B). The signs of the path coefficients indicate that moister and sandy soils increases soil acidity. In the case of carbon and nitrogen, gradients seem to be exclusively and intensively related to plant community composition; the rest of landscape- and field-scale control factors have only indirect effects (Figure 4C). However, indirect effects from soil moisture ( 0.301 for carbon and 0.256 for nitrogen) and climate ( 0.456 for carbon and 0.358 for nitrogen) should be also taken into account. Finally, no direct nor indirect effects may explain the phosphorous gradient.

\section{DISCUSSION}

This study highlights the spatial variation of soil properties of meadows in a large region. We distinguished a variety of potential abiotic and biotic factors that control these gradients and operate at two different scales: landscape and field. The proposed modeling approach is of general interest and can be used for other soil gradients anywhere in the world. Here we have presented a case study of a landscape that is characterized by large environmental gradients that include a variety of ecological scenarios.

\section{Variation in soil chemical composition in montane meadows}

We found that total ion content and soil acidity are the major and independent sources of spatial variation of soil geochemistry in these silicicolous Mediterranean montane meadows. This result is in agreement with the findings of Herrera (1987) and Bernáldez \& Rey Benayas (1992). They 
studied the spatial variation of soil meadow geochemistry in two sandy, arkosic plateaus adjacent to our study area. Thus, the main variation trends in soils derived from both parent materials, namely granite and arkoses, are similar. However, the range and mean of soil variables in both systems are very different. In the Northern Plateau, soil conductivity in wet meadows ranged between 33 and $4130 \mu \mathrm{S} \mathrm{cm}{ }^{-1}$ and averaged $650 \mu \mathrm{S} \mathrm{cm}^{-1}$, whereas soil pH ranged between 6.4 and 9.6 and averaged 7.8 ( $n=156$ soil samples, see Table 1 for comparison with the statistics of this study). These contrasting values are ultimately controlled by groundwater flow length, groundwater table depth, evaporation, and topography (Arndt \& Richardson 1989; Bernáldez \& Rey Benayas 1992; Raji \& Alagbe 2000). As compared to the hydrological system in mountains, the longer flow length allows a higher ion content in groundwater outcrops, and the higher evaporation rates and flatter topography facilitate solute concentration in topsoil.

We hypothesized a close relationship between variation in soil chemical composition and elevation. The existence of such a type of gradients could be easily related to latitudinal trends widening the spatial perspectives of our regional scale study. We found this lineal relationship for acidity, carbon, and nitrogen, but not for total ion content and phosphorous. The strong correlation between carbon and nitrogen hint to similar explanatory models of their variation.

\section{Explanatory models for gradients of soil chemical composition}

We built a priori model for explanation of gradients of soil chemical composition that was tested by means of SEM and included factors operating at two contrasting spatial scales. The evaluation of the proposed model for the five gradients resulted in a common set of relationships among the control variables: climate and land form (landscape-scale control factors) and topography, soil texture, soil moisture, and plant community (field-scale control factors). 
We hypothesized that climate and land form affected topography. As expected, our model highlighted the importance of land form in shaping topography. Local topography reinforces the exportation-importation gradient found at a landscape-scale. However, in spite of the positive correlation between climate and topography and contrary to our hypothesis, this path can not be considered significantly different from zero. Boix-Fayos et al. (1998) found in another Mediterranean mountainous landscape an increase in runoff coefficients and erosion when climate becomes more arid. The model validated the climate effects on plant community composition (Barbour et al. 1987). Similarly, it also includes a positive and large link between climate and soil moisture probably mediated through precipitation and evaporation regimes (Rey Benayas et al. 1998; Rey 1999).

We also hypothesized that soil texture was at least partially controlled by land form and topography. The model resulted in a significant effect of land form on soil texture, but the effect of topography was not significant in spite of the correlation between soil texture and topography. Thus, in a multivariate context, piedmont positions preferably accumulate fine textured materials whereas bottom topographic positions hardly have any influence. Literature shows contrasting responses at this level. Boix-Fayos et al. (1998) found a regional gradient for clay content that was positively related to precipitation, whereas topography affected other soil properties such as aggregation and infiltration. Similarly, Reese \& Moorhead (1996) found a relationship between texture and topographic position, whereas Rahman et al. (1996) did not find any significant relationship between texture and terrain attributes such as elevation, slope gradient and slope shape.

Soil texture affected soil moisture but topography did not. We have observed that groundwater outcropping frequently occurs in steep slopes through sandy material (Rey Benayas et al. 1998). Thus, the balance between our field observations that steeper slopes "provide drainage that favors loss of soil water" and that "also contribute to outcropping of 
groundwater that moistens soils” results in a neutral effect of topography on soil moisture. The positive effect of coarse-textured soils on soil moisture is attributed to groundwater outcropping from fractured, sandy material. Groffman et al. (1996) also found that clay meadow wetlands were drier than other wetland types. However, Yeakley et al. (1998) found that in the upper soil depth $(0-30 \mathrm{~cm})$ topography exerted a dominant control on moisture gradients, whereas for the entire root zone $(0-90 \mathrm{~cm})$ soil moisture gradients were controlled by both topography and storage before drought related to soil texture and horizon distribution. Fitzjohn et al. (1998) found in a semi-arid Mediterranean catchment that the spatial pattern of soil moisture was characterized by a mosaic of areas of relatively wet and dry soil with contrasting hydrological response. These areas were spatially isolated and unconnected, with the effect that surface runoff from source areas may be re-absorbed by surrounding areas, which act as sinks for overland flow. A similar mechanism could be operating in our zone, and so explaining the absence of relationships between soil moisture and topography.

The model also suggested a direct effects of climate, soil texture, soil moisture, and plant communities on gradients of soil chemical composition. Climate did not have any direct effect on these gradients; all effects of climate were indirect through plant community composition and/or soil moisture. One of the most important conclusions of our work is that the described gradients are controlled by three types of factor combinations. First, a predominantly biotic control, namely plant community composition. In our study, gradients of carbon and nitrogen are exclusively related to this biotic control type. Some studies have shown that plant communities affect soil $\mathrm{C}$ and $\mathrm{N}$ patterns through changes in soil abiotic features such as moisture and texture (Hibbard et al. 2001). Our results are congruent with the suggestions of Reese \& Moorhead (1996) who pointed out that differences in soil parameters in the A horizon may be a reflection of vegetation patterns or hydrology in a temperate wetland. Conversely to our results, Burke et al. (1999) found that the largest spatial variation for total 
soil $\mathrm{C}$ and $\mathrm{N}$ occurs in concert with topography and with microsite-scale heterogeneity, with relatively little spatial variability due to plant species. Davidson (1995) identified several factors affecting stocks of soil organic-C, including climate, soil texture, and drainage. However, Gonzalez \& Zak (1994) found that fine-scale spatial patterns of net N mineralization and net nitrification were likely driven by overstory litter inputs, rather than variation in soil texture and water availability.

Dominant abiotic mechanisms, namely soil moisture and texture, control other gradients. Soil acidity is strongly related to soil moisture and texture and marginally related to plant community composition $(\mathrm{P}<0.07)$. Sival \& Grootjans (1996) found that a regular supply of acid components buffers the $\mathrm{pH}$ and slows down the accumulation of organic matter.

A third control type comprising biotic and abiotic factors also arises. Total ionic content is simultaneously and directly controlled by plant community and soil moisture. Blackstock et al. (1998) indicated that the main differences in soil conditions between vegetation types in lowland Wales were related to gradients in base-status and apparent variation in soil fertility. Finally, as a last control alternative, no direct, nor indirect effects may explain the gradient of phosphorous, probably due to the large spatial variability of this nutrient (Bolland \& Allen 1998).

As hypothesized, direct effects of plant community composition are important to explain gradients of soil chemical composition except in the case of phosphorous concentration and only marginally in acidity. Plant community composition in turn is a syndrome of many features that potentially may influence these gradients (Aerts et al. 1999). Some of these features are the quantity and quality of biomass yielded to soils (Steltzer and Bowman 1998, Hokkanen et al. 1995), root biomass (Gao et al. 1996), decomposition rates (Roy 1996), growth form (Bowman et al. 1995), deciduous or evergreen character, N-fixing properties, phenology, etc. We did not measure these features in the field and thus we cannot pursue 
further more explicit mechanisms. We want to point out that this hypothesized effect have received little attention by ecologists, who have mostly looked at the effects of soil on plant community composition.

\section{Plausible Effects of Global Change}

The model highlighted the relative unimportance of direct effects of climate on gradients of soil chemical composition but important indirect effects through soil moisture and plant community composition. In the area, climate is predicted to turn more arid due to lower precipitation and higher temperature that would result in increasing evaporation rates (Barry 1992, IPCC 1995, Oñate \& Pou 1996). Linusson et al. (1998) found in a 30-year-time span for another meadow system that the main vegetation differences were due to variation in soil moisture. During their investigation period, the amount of area of wet-moist meadows decreased. Harte et al. (1995) run heating experiments of soils that highlighted that heating advanced snow melt by approximately 1 week, increased summer soil temperatures by up to 3 ${ }^{\circ} \mathrm{C}$, and reduced summer soil moisture levels by up to $25 \%$ compared to control plots. Our results point to that dryer soils will directly result in less acid, more neutral soils and with lower ion concentration, i.e. fertility. Changes in plant community composition through climate (de Valpine and Harte 2001) or by any direct or indirect human influence (e.g. fertilization, deforestation and ruderalization by increasing recreational activities) will result in changes in gradients of soil carbon (Conant et al. 2001), nitrogen, ion content, and acidity. We conclude that testing models such as the one presented in this study are a promising tool to explain gradients of soil chemical composition and the effects of global change on them. 


\section{ACKNOWLEDGEMENTS}

We are indebted to Antonio Gallardo, Agustín Rubio and Sam Scheiner for their comments on a preliminary version of this manuscript. An anonymous reviewer improved its final version. Financial support has been obtained from the projects C129/91 (Comunidad de Madrid) and REN 2000-0745 (Ministerio de Ciencia y Tecnología).

\section{REFERENCES}

Aerts R, Verhoeven JTA \& Whigham DF (1999) Plant-mediated controls on nutrient cycling in temperate fens and bogs. Ecology 80: 2170-2181.

Albert MJ, Escudero A \& Iriondo JM. (2001) Female reproductive success of narrow endemic Erodium paularense in contrasting microhabitats. Ecology 82: 1734-1747.

Arndt JL \& Richardson JL (1989) Geochemistry of hydric soil salinity in a rechargethroughflow- discharge prairie-pothole wetland system. Soil Sci. Soc. Am. J. 53: 848-855.

Athavale RN, Rangarajan R \& Muralidharan D (1998) Influx and efflux of moisture in a desert soil during a 1 year period. Water Resources Res. 34: 2871-2877.

Barbour MG, Burk JH \& Pitts WD (1987) Terrestrial Plant Ecology. The Benjamin/Cummings Publishing Company, Menlo Park (CA).

Barry RG (1990) Changes in mountain climate and glacio hydrological responses. Mountain Res. Dev. 10: 161-170.

Barry RG (1992) Mountain climatology and past and potential future climatic changes in mountain regions: a review. Mountain Res. Dev. 12: 71-86.

Bentler PM (1989) EQS structural equations program manual. BMDP Statistical Software, Los Angeles. 
Bernáldez FG. \& Rey Benayas JM (1992) Geochemical relationships between groundwater and wetland soils and their effects on vegetation in central Spain. Geoderma 55: 273-288.

Bernáldez FG, Rey Benayas JM \& Martínez A (1993) Ecological impact typology on wetlands produced by groundwater extraction (Douro River, Spain). J. Hydrol. 141: 219238.

Blackstock TH, Stevens DP, Stevens PA, Mockridge CP \& Yeo MJM (1998) Edaphic relationships among Cirsio-Molinietum and related wet grassland communities in lowland Wales. J. Veg. Sci. 9: 431-444.

Blank RR, Svejcar TJ \& Riegel GM (1995) Soil genesis and morphology of a montane meadow in the northern Sierra Nevada range. Soil Sci. 160: 136-152.

Boix-Fayos C, Calvo Cases A, Imeson AC, Soriano Soto MD \& Tiemessen IR (1998) Spatial and short term temporal variations in runoff, soil aggregation and other soil properties along a Mediterranean climatological gradient. Catena 33: 123-138.

Bolland MDA \& Allen DG (1998) Spatial variation of soil test phosphorus and potassium, oxalate-extractable iron and aluminum, phosphorus-retention index, and organic carbon content in soils of Western Australia. Comm. Soil Sci. Plant Anal. 29: 381-392.

Bouten W \& Witter JV (1992) Modeling soil water dynamics in a forest ecosystem. II: evaluation of spatial variation of soil profiles. Hydrol. Processes 6: 445-454.

Bowman WD, Theodose TA \& Fisk MC (1995) Physiological and production responses of plant growth forms to increases in limiting resources in alpine tundra: Implications for differential community response to environmental change. Oecologia (Berlin) 101: 217227.

Boyoucos G (1935) Journal of the American Society of Agronomy. American Society Testing Material (ASTM) no. $152 \mathrm{H}$. 
Burke IC (2000) Biogeochemistry in a shortgrass landscape: control by topography, soil texture, and microclimate. Ecology 81: 2686-2703.

Burke IC, Lauenroth WK, Riggle R, Brannen P, Madigan B \& Beard S (1999) Spatial variability of soil properties in the shortgrass steppe: The relative importance of topography, grazing, microsite, and plant species in controlling spatial patterns. Ecosystems 2: 422-438.

Buse A (1982) The likehood ratio, Wald and Lagrange multiplier tests: an expository note. Am. Statistician 36: 153-157.

Butterworth JA, Schulze RE, Simmonds LP, Moriarty P \& Mugabe F (1999a). Hydrological processes and water resources management in a dryland environment IV: Long-term groundwater level fluctuations due to variation in rainfall. Hydrol. Earth Syst. Sci. 3: 353361.

Butterworth JA., Macdonald DMJ, Bromley J, Simmonds LP, Lovell CJ \& Mugabe F (1999b) Hydrological processes and water resources management in a dryland environment III: Groundwater recharge and recession in a shallow weathered aquifer. Hydrol. Earth Syst. Sci. 3: 345-352.

Callaway RM (1995) Positive interactions among plants. Bot. Rev. 61: 306-349.

Callaway RM (1997) Positive interactions in plant communities and the individualisticcontinuum concept. Oecologia 112: 143-149.

Chatterjee S, Price B (1991) Regression analysis by example, $2^{\text {nd }}$ ed. John Wiley \& Sons, New York.

Colomer MGS (1998) Heterogeneidad del medio abiótico, composición florística y diversidad en humedales montanos mediterráneos (sierra de Guadarrama). Ph. D. Thesis, Universidad Autónoma de Madrid, Madrid, Spain. 
Conant RT, Paustian K \& Elliot ET (2001) Grassland management and conversion into grassland: effects on soil carbon. Ecol. Applic. 11: 343-355.

Crawford CAG \& Hergert GW (1997) Incorporating spatial trends and anisotropy in geostatistical mapping of soil properties. Soil Sci. Soc. Am. J. 61: 298-309.

Davidson EA (1995) Spatial covariation of soil organic carbon, clay content, and drainage class at a regional scale. Landscape Ecol. 10: 349-362.

De Valpine P \& Harte J (2001) Plant responses to experimental warming in a montane meadow. Ecology 82: 637-648.

Fitzjohn C, Ternan JL \& Williams AG (1998) Soil moisture variability in a semi-arid gully catchment: Implications for runoff and erosion control. Catena 32: 55-70.

Gao Q, Li J \& Zheng H (1996) A dynamic landscape simulation model for the alkaline grasslands on Songnen Plain in northeast China. Landscape Ecol. 11: 339-349.

Giesler R, Hogberg M \& Hogberg P (1998) Soil chemistry and plants in Fennoscandian boreal forest as exemplified by a local gradient. Ecology 79: 119-137.

Gilmanov TG, Parton WJ \& Ojima DS (1997) Testing the 'CENTURY' ecosystem level model on data sets from eight grassland sites in the former USSR representing a wide climatic/soil gradient. Ecol. Model. 96: 191-210.

Goderya FS (1998) Field scale variations in soil properties for spatially variable control: A review. J. Soil Cont. 7: 243-264.

Gonzalez OJ \& Zak DR (1994) Geostatistical analysis of soil properties in a secondary tropical dry forest, St. Lucia, West Indies. Plant Soil 163: 45-54.

Goovaerts P \& Chiang CN (1993) Temporal persistence of spatial patterns for mineralizable nitrogen and selected soil properties. Soil Sci. Soc. Am. J. 57: 372-381. 
Grigal DF, McRoberts RE \& Ohmann LF (1991) Spatial variation in chemical properties of forest floor and surface mineral soil in the north central United States. Soil Sci. 151: 282290.

Groffman PM, Hanson GC, Kiviat E \& Stevens G (1996) Variation in microbial biomass and activity in four different wetland types. Soil Sci. Soc. Am. J. 60: 622-629.

Harte J, Torn MS, Chang FR, Feifarek B, Kinzig AP, Shaw R \& Shen K (1995) Global warming and soil microclimate: Results from a meadow-warming experiment. Ecol. Applic. 5: 132-150.

Hayduk LA (1987) Structural Equation Modeling with LISREL. Essentials and Advances. The John Hopkins University Press, BA.

Herrera P (1987) Aspectos ecológicos de las aguas subterráneas en la facies arcósica de la cuenca de Madrid. Ph. D. Thesis. Universidad de Alcalá de Henares, Madrid, Spain.

Hibbard KA, Archer S, Schimel DS \& Valentine DW (2001) Biogechemical changes accompanying woody plant encroachment in a subtropical savanna. Ecology 82: 10992011.

Hokkanen TJ, Jarvinen E \& Kuuluvainen T (1995) Properties of top soil and the relationship between soil and trees in a boreal Scots pine stand. Silva Fennica 29: 189-203.

Intergovernmental Panel on Climate Change (IPCC) (1995) Climate Change 1994: Radiative forcing of climate change and evaluation of the IPCC IS92 Emission Scenarios. Cambridge Univ. Press, Cambridge.

Jarolimek I, Banasova V \& Otahelova H (2000) Changes in alluvial grassland vegetation in relation to flood dynamics and soil moisture. Ekologia-Bratislava 19: 39-53.

Johnson LC, Shaver GR, Cades DH, Rastetter E, Nadelhoffer K, Giblin A, Laundre J \& Stanley A (2000) Plant carbon-nutrient interactions control CO2 exchange in Alaskan wet sedge tundra ecosystems. Ecology 81: 453-469. 
Kumar A, Kuhad MS, Grewal MS \& Dahiya IS (1996) Evaluation of spatial variation in some soil properties of alluvial plains. Arid Soil Res. Rehab. 10: 21-30.

Lev A. \& King RH (1999) Spatial variation of soil development in a high arctic soil landscape: Truelove Lowland, Devon Island, Nunavut, Canada. Permafrost Periglacial Processes 10: 289-307.

Linusson AC, Berlin GA \& Olsson EGA (1998) Reduced community diversity in seminatural meadows in southern Sweden, 1965-1990. Plant Ecol. 136: 77-94.

Loehlin JC (1987) Latent variable models. Lawrence Erlbaum, Hillsdale, NJ, USA.

McCune B \& Mefford MJ (1995) PC-ORD. Multivariate Analysis of Ecological Data, Version 2.0. MjM Software Design, Gleneden Beach, OR, USA.

Meinzer FC, Andrade JL, Goldstein G, Holbrook NM, Cavelier J \& Wright SJ (1999) Partitioning of soil water among canopy trees in a seasonally dry tropical forest. Oecologia 121: 293-301.

Mitchell RJ (1992) Testing evolutionary and ecological hypotheses using path analysis and structural equation modeling. Funct. Ecol. 6: 123-129.

Mitchell RJ (1993) Path analysis: pollination. In Scheiner SM \& Gurevitch J (Eds) Design and Analysis of Ecological Experiments (pp 211-231). Chapman and Hall, New York.

Moustafa MM \& Yomota A (1998) Use of a covariance variogram to investigate influence of subsurface drainage on spatial variability of soil-water properties. Agric. Water Manag. 37: $1-20$.

Oñate J \& Pou A (1996) Temperature variations in Spain since 1901: a preliminary analysis. Int. J. Climat. 16: 805-815.

Petraitis PS, Dunham AE \& Niewiarowski PH (1996) Inferring multiple causality: the limitations of path analysis. Funct. Ecol. 10: 421-431. 
Rahman S, Munn LC, Zhang R \& Vance GF (1996) Rocky mountain forest soils: evaluating spatial variability using conventional statistics and geostatistics. Can. J. Soil Sci. 76:501507.

Raji BA \& Alagbe SA (2000) A topo-geochemical sequence study of groundwater in Asa drainage basin, Kwara State, Nigeria. Env. Geol. 39: 544-548.

Reese RE \& Moorhead KK (1996) Spatial characteristics of soil properties along an elevational gradient in a Carolina bay wetland. Soil Sci. Soc. Am. J. 60: 1273-1277.

Rey JM (1999) Modeling potential evapotranspiration of potential vegetation. Ecol. Model. 123: 141-159.

Rey Benayas JM (1995) Patterns of diversity in the strata of boreal montane forest in British Columbia. J. Veg. Sci. 6: 95-98.

Rey Benayas JM., Colomer MGS, Levassor C \& Vázquez-Dodero I (1998) The role of wet grasslands in biological conservation in Mediterranean landscapes. In Joyce CB \& Wade PM (Eds) European wet grasslands: biodiversity, management and restoration (pp. 61-72). John Wiley, Chichester (UK).

Rey Benayas JM., García S.-Colomer M \& Levassor C (1999) Effects of area, environmental status and environmental variation on species richness per unit area in Mediterranean wetlands. J. Veg. Sci. 10: 275-280.

Roy S (1996) Spatial variation of soil physico-chemical properties influenced by spatial and temporal variation of litter in a dry tropical forest floor. Oecologia Montana 5: 21-26.

Sanz C (1988) El relieve del Guadarrama Oriental. Comunidad de Madrid, Madrid, Spain. SAS Institute (1990) SAS/STAT User’s guide. Rel. 6.04. SAS Institute, Cary, NC, USA. Shipley B (1999) Testing causal explanations in organismal biology: causation, correlation and structural equation modeling. Oikos 86: 374-382. 
Sinowski W \& Auerswald K (1999) Using relief parameters in a discriminant analysis to stratify geological areas with different spatial variability of soil properties. Geoderma 89: 113-128.

Sival FP \& Grootjans AP (1996) Dynamics of seasonal bicarbonate supply in a dune slack: Effects on organic matter, nitrogen pool and vegetation succession. Vegetatio 126: 39-50.

Steltzer H \& Bowman WD (1998) Differential influence of plant species on soil nitrogen transformations within moist meadow alpine tundra. Ecosystems 1: 464-474.

Stottlemyer R \& Troendle CA (1999) Effect of subalpine canopy removal on snowpack, soil solution, and nutrient export, Fraser Experimental Forest, CO. Hydrol. Processes 13: 22872299.

Strong DT, Sale PWG \& Helyar KR (1998) The influence of the soil matrix on nitrogen mineralisation and nitrification. I. Spatial variation and a hierarchy of soil properties. Aust. J. Soil Res. 36: 429-447.

Tanaka JS (1987) 'How big is big enough?': sample size and goodness of fit in structural equation models with latent variables. Child Dev. 58: 134-146.

Tanaka JS \& Huba GJ (1985) A fit index for covariance structure models under arbitrary GLS estimation. Brit. J. Math. Stat. Psyc. 38: 197-201.

Thornwaite CW (1948) An approach toward a rational classification of climate. Geog. Rev. 38: 55-94.

Updegraff K, Pastor J, Bridgham SD \& Johnston CA (1995) Environmental and substrate controls over carbon and nitrogen mineralization in northern wetlands. Ecol. Applic. 5: 151-163.

Van Breemen N, Mulder J \& Discoll CT (1983) Acidification and alcalinization of soils. Plant Soil 75: 283-308. 
Vervoort NW, Radcliffe DE \& West LT (1999) Soil structure development and preferential solute flow. Water Resources Res. 35: 913-928.

Wang GG \& Klinka K (1996) Classification of moisture and aeration regimes in sub-boreal forest soils. Env. Monit. Asses. 39: 451-469.

Weisberg PJ \& Baker WL (1995) Spatial variation in tree seedling and Krummholz growth in the forest-tundra ecotone of Rocky Mountain National Park, Colorado, USA. Arctic Alp Res 27: 116-129.

Wendroth O, Pohl W, Koszinski S, Rogasik H, Ritsema CJ \& Nielsen DR (1999) Spatiotemporal patterns and covariance structures of soil water status in two Northeast-German field sites. J. Hydrol. 215: 38-58.

Yeakley JA, Swank WT, Swift LW, Hornberger GM \& Shugart HH (1998) Soil moisture gradients and controls on a southern Appalachian hillslope from drought through recharge. Hydrol. Earth Syst. Sci. 2: 41-49. 
Figure legends

Figure 1. The hypothesized model of spatial variation of soil properties, with distinction of scale components. Link numbers match text in Methods. Links in bold are direct effects on gradients of ion content, acidity, carbon, nitrogen and phosphorous.

Figure 2. Variation of various hypothesized control factors of soil chemical composition along the altitudinal gradient in the study area. A) Thornwaite's (1948) water index. B) Topographic slope. C) Soil moisture, numbers in the Y axis correspond to soil hygrotype according to Rey Benayas et al. (1998). D) Sand proportion.

Figure 3. Relationships between elevation and A) total ion content in soils (first Principal Component of soil geochemistry); B) soil acidity (second Principal Component of soil geochemistry, note that for this component the samples with lower loadings are more acid); C) carbon; D) total nitrogen; and E) total phosphorous concentration.

Figure 4. Results of the Structural Equation Modeling for gradients of soil chemical composition. A) total ion content, B) acidity, C) carbon. The model for total nitrogen is very similar to that for carbon. Highlighted arrows indicate significant path coefficients between variables (continuous arrows for positive relationships and dotted arrows for negative relationships). The breadth of the arrow is proportional to the standardized path coefficient. Notes: see Methods for the actual measures used to quantify the different variables; the small differences in the path coefficients between control variables in the carbon model as compared to the total ion content and acidity models are related to sample size (Table 1). 
Table 1.- Mean, standard deviation, and range of the variables sampled in meadow soils that were included in the Structural Equation Modeling (SEM). Notes: land form and plant community composition are not included in the table because they were estimated by means of a consensus multivariate variable; the three texture fractions were collapsed into one principal component (see text); electrical conductivity and $\mathrm{pH}$ are the most representative single variables of two principal components, namely soil total ion content and soil acidity, that were actually used in the SEM (see text).

\begin{tabular}{l|lll} 
Variable & Mean \pm SD & Range & N \\
\hline Thornwaités Water Index & $89.43 \pm 51.98$ & $-8.3-168.3$ & 92 \\
Topographic slope $\left.\mathbf{(}^{\circ}\right)$ & $6.17 \pm 6.21$ & $0-26$ & 92 \\
Soil hygrotype & $4.62 \pm 2.16$ & $1-7$ & 92 \\
Sand (\%) & $63.87 \pm 13.17$ & $28-59$ & 82 \\
Silt (\%) & $26.59 \pm 7.59$ & $12-50$ & 82 \\
Clay (\%) & $9.55 \pm 8.00$ & $1-37$ & 82 \\
Electrical conductivity $\left(\boldsymbol{\mu S} \mathbf{c m}^{-1}\right)$ & $70.9 \pm 47.8$ & $20.8-357.0$ & 91 \\
pH & $6.4 \pm 0.5$ & $5.3-8.0$ & 91 \\
C (\%) & $5.89 \pm 4.98$ & $0.92-33.9$ & 91 \\
N (\%) & $0.39 \pm 0.31$ & $0.0002-2.21$ & 91 \\
P (me L $\left.{ }^{-1}\right)$ & $0.202 \pm 0.177$ & $0.066-1.189$ & 89
\end{tabular}


Table 2.- Results of the Principal Component Analysis performed on soil pH, electrical conductivity, $\mathrm{Na}^{+}, \mathrm{K}^{+}, \mathrm{Ca}^{2+}, \mathrm{Mg}^{2+}, \mathrm{SO}_{4}{ }^{2-}, \mathrm{Cl}^{-}$, and $\mathrm{CO}_{3} \mathrm{H}^{-}$(n $=90$ composed 20-cm-depth soil samples). Values in bold correspond to the highest contributions of the individual variables to the principal components. Percent of accounted variance for each component in parenthesis.

\begin{tabular}{l|cc} 
Geochemical variables & First PC (54.6 \%) & Second PC (15.2 \%) \\
\hline $\mathbf{p H}$ & -0.0429 & $\mathbf{0 . 5 5 6 1}$ \\
Electrical Conductivity & $\mathbf{0 . 4 2 1 9}$ & -0.1079 \\
$\mathbf{N a}^{+}$ & 0.3454 & -0.3947 \\
$\mathbf{K}^{+}$ & 0.2817 & 0.1485 \\
$\mathbf{C a}^{2+}$ & 0.3731 & 0.2809 \\
$\mathbf{M g}^{2+}$ & 0.4133 & 0.0617 \\
$\mathbf{S O}_{4}{ }^{2}$ & 0.3932 & 0.0146 \\
$\mathbf{C l}^{-}$ & 0.3041 & -0.3583 \\
$\mathbf{C O}_{3} \mathbf{H}$ & 0.2540 & 0.5385
\end{tabular}

Table 3.- Pair-wise correlations between the six control factors of gradients of soil chemical composition used in the model. ${ }^{* * *} \mathrm{P}<0.0001$; ${ }^{* * *} \mathrm{P}<0.001$; ${ }^{* *} \mathrm{P}<0.01$; ${ }^{*} \mathrm{P}<0.05$; (n) is the number of observations. Bolded numbers are those correlation coefficients that remain significant at $\mathrm{P}<0.05$ if Bonferroni corrections were applied.

\begin{tabular}{|c|c|c|c|c|c|}
\hline & $\begin{array}{c}\text { Thornwaite's Water } \\
\text { Index }\end{array}$ & Soil moisture & $\begin{array}{c}\text { Topographic } \\
\text { slope }\end{array}$ & Soil texture & Land form \\
\hline Soil moisture & $\mathbf{0 . 7 3 ^ { * * * * }}(92)$ & & & & \\
\hline $\begin{array}{l}\text { Topographic } \\
\text { slope }\end{array}$ & $\mathbf{0 . 4 5 ^ { * * * * }}(92)$ & $0.31^{* *}(92)$ & & & \\
\hline Soil texture & $-0.39^{* * *}(82)$ & $-0.37^{* * *}(82)$ & $-0.35^{* *}(82)$ & & \\
\hline Land form & $-\mathbf{0 . 8 0 ^ { * * * * }}(92)$ & $-\mathbf{0 . 6 3} 3^{* * * *}(92)$ & $-\mathbf{0 . 5 1}^{* * * *}(92)$ & $\mathbf{0 . 4 7 ^ { * * * * }}(82)$ & \\
\hline $\begin{array}{l}\text { Plant community } \\
\text { composition }\end{array}$ & $-\mathbf{0 . 7 6}^{* * * *}(85)$ & $-\mathbf{0 . 7 8}^{* * * *}(85)$ & $-0.42^{* * * *}(85)$ & $0.26^{*}(75)$ & $0.72^{* * *}(85)$ \\
\hline
\end{tabular}




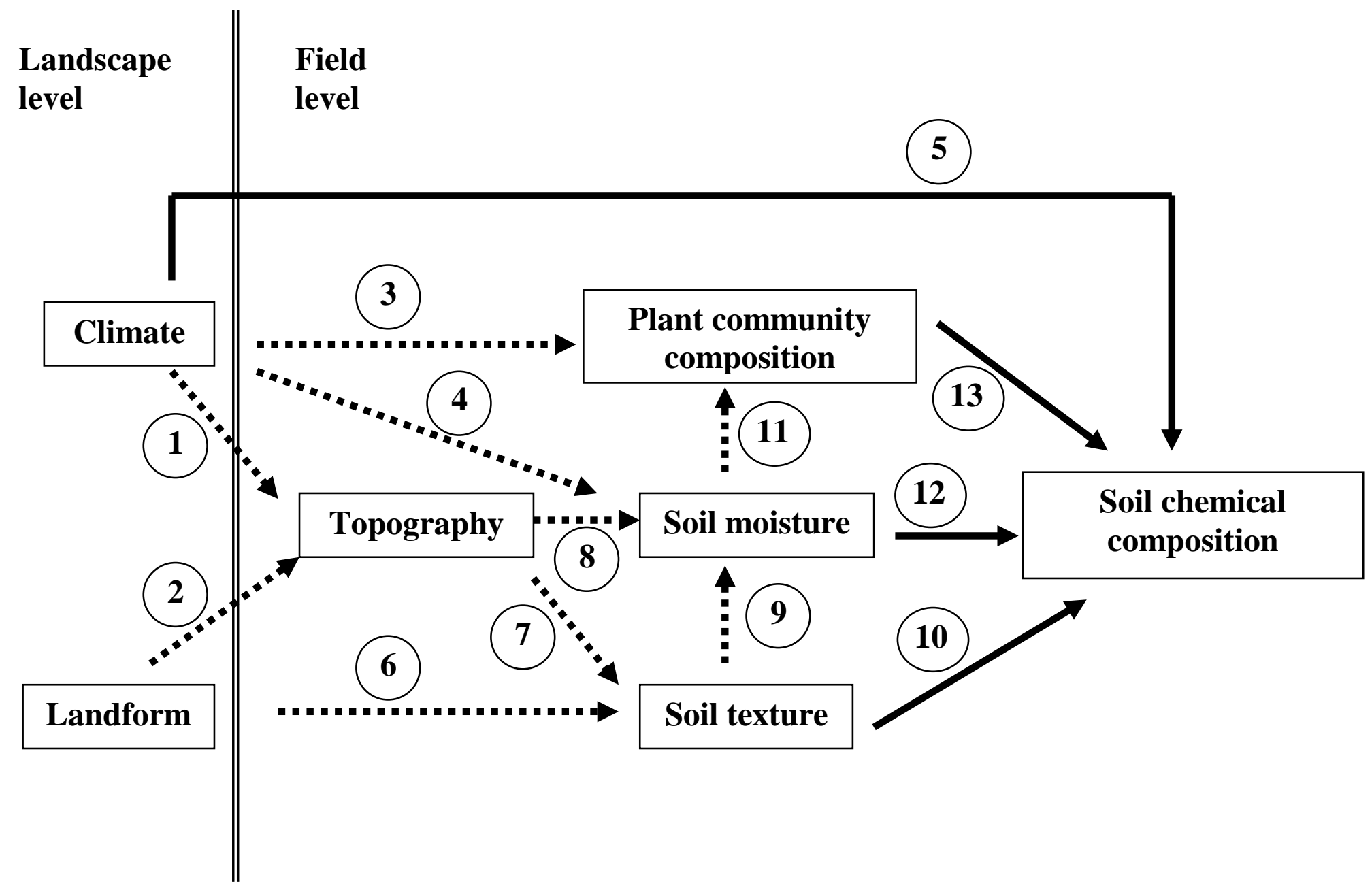

Fig. 1 

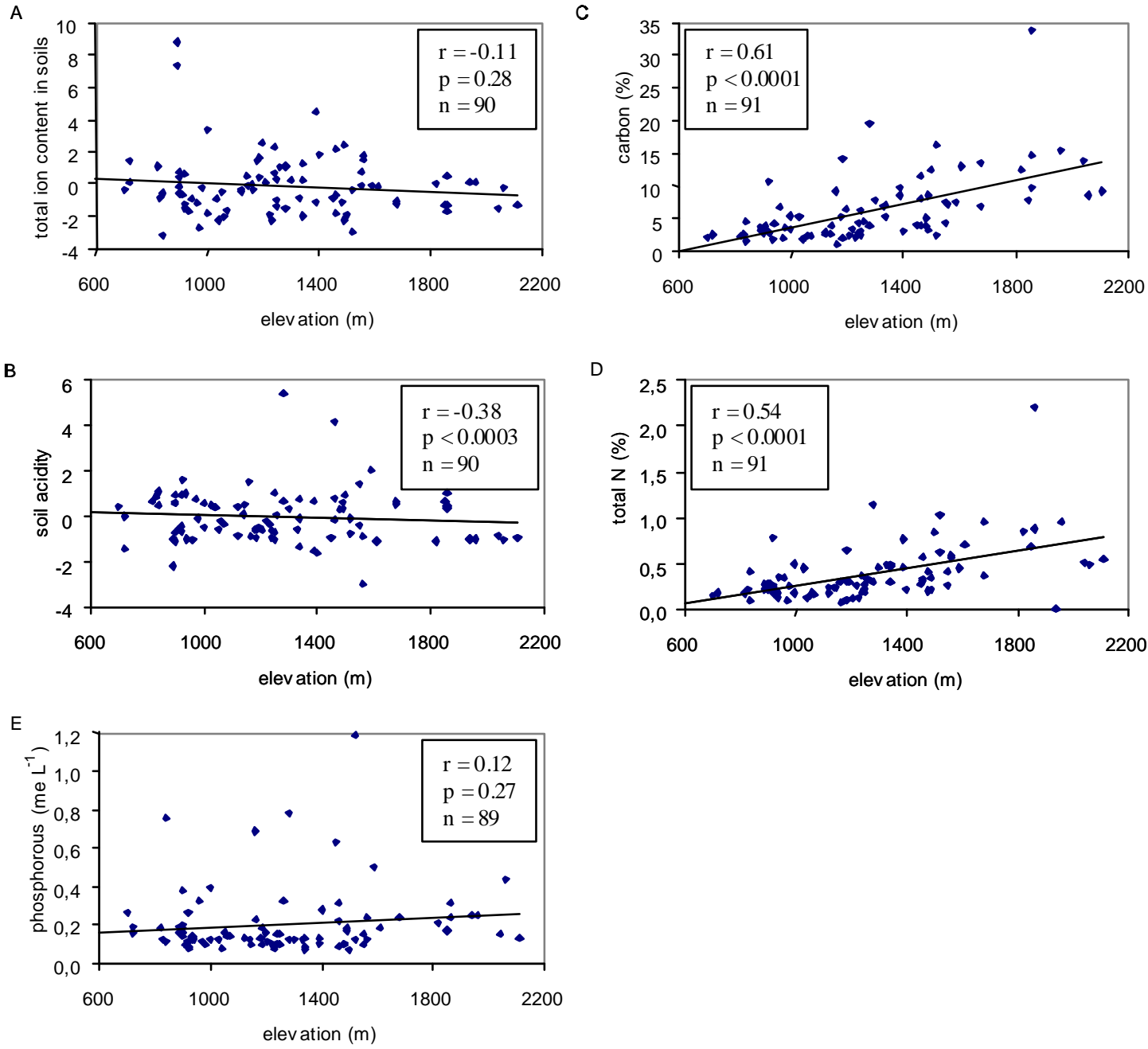

Fig. 3 


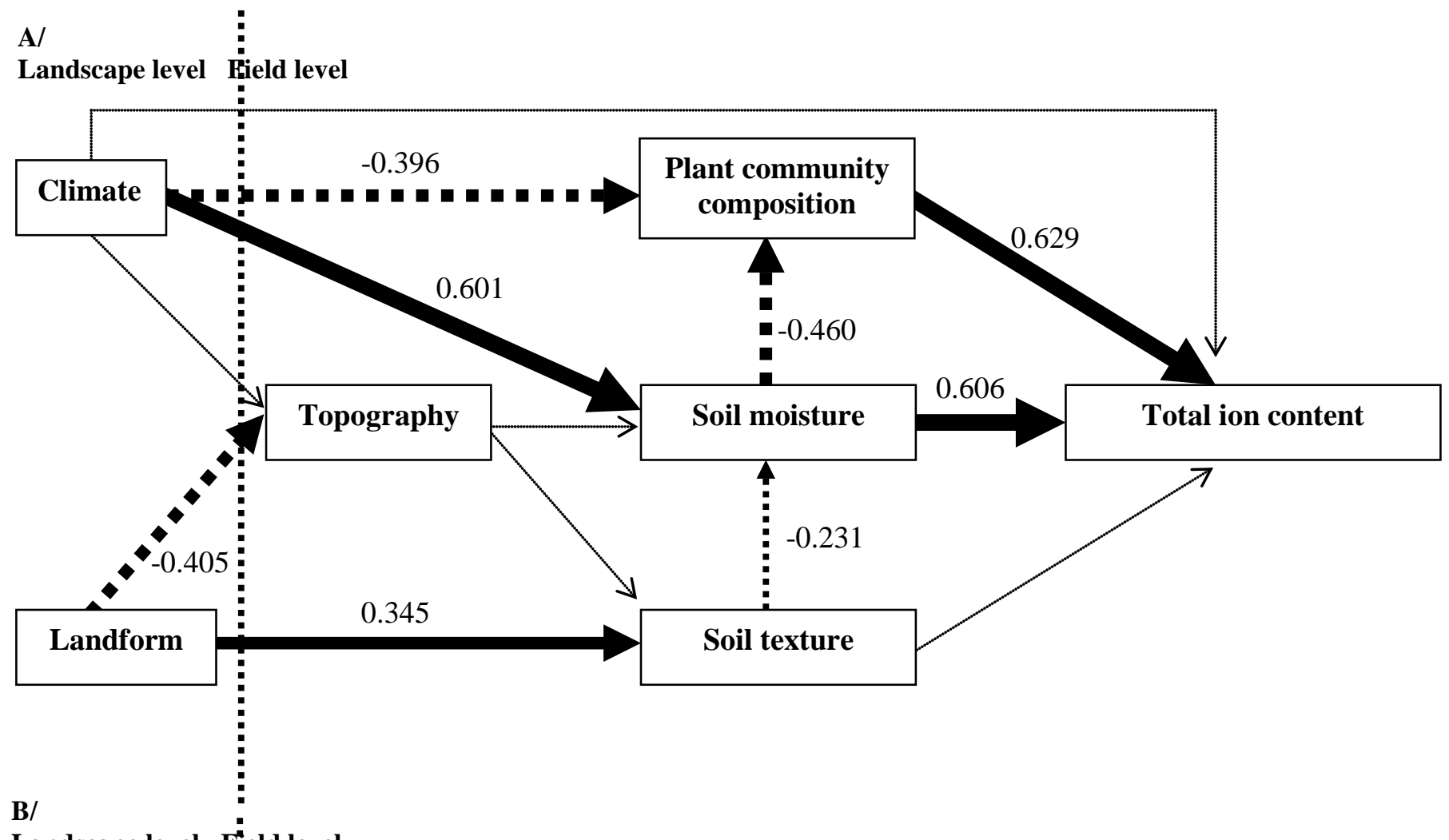

Landscape level Figeld level

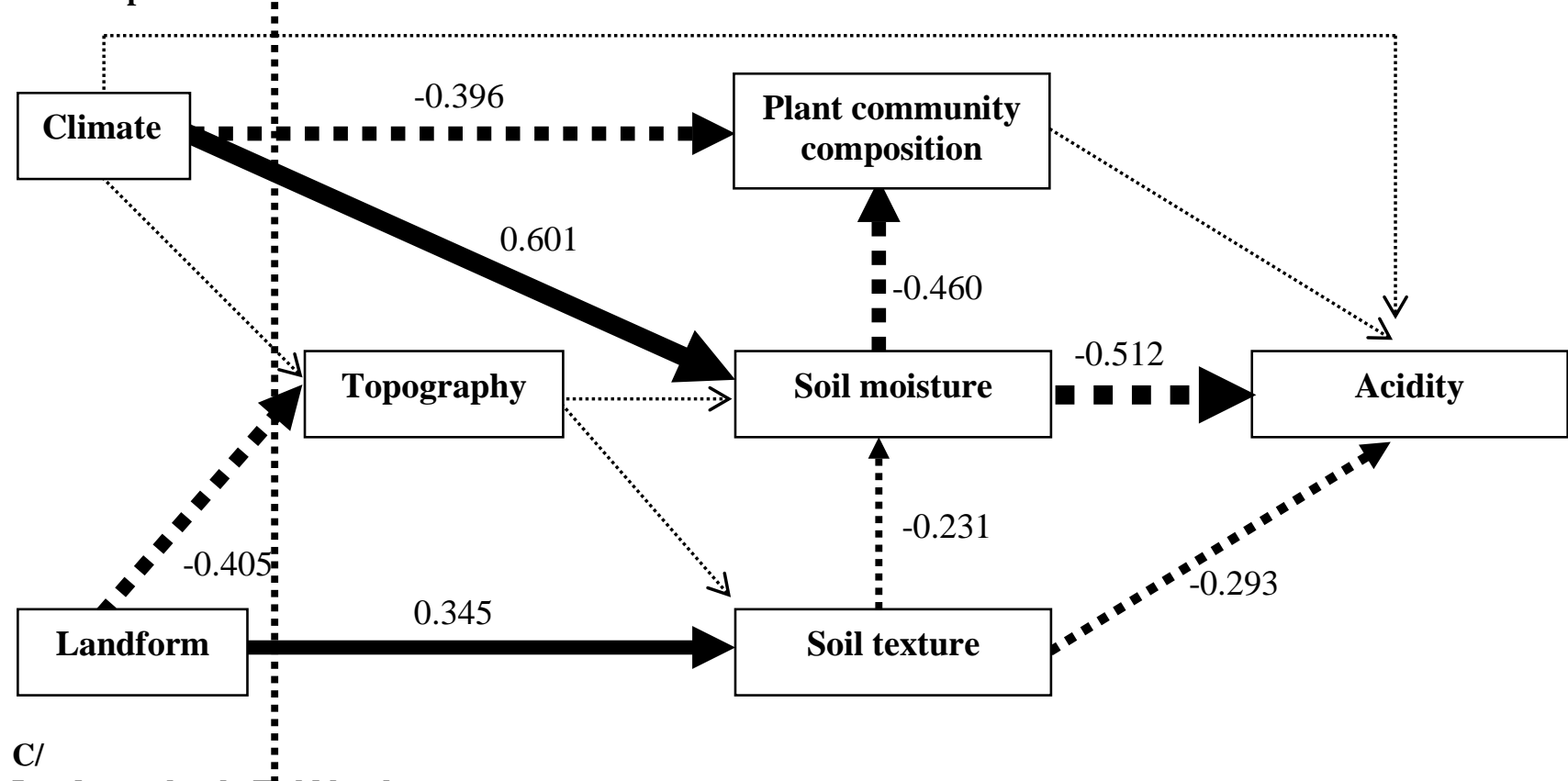

Landscape level Fạtd level

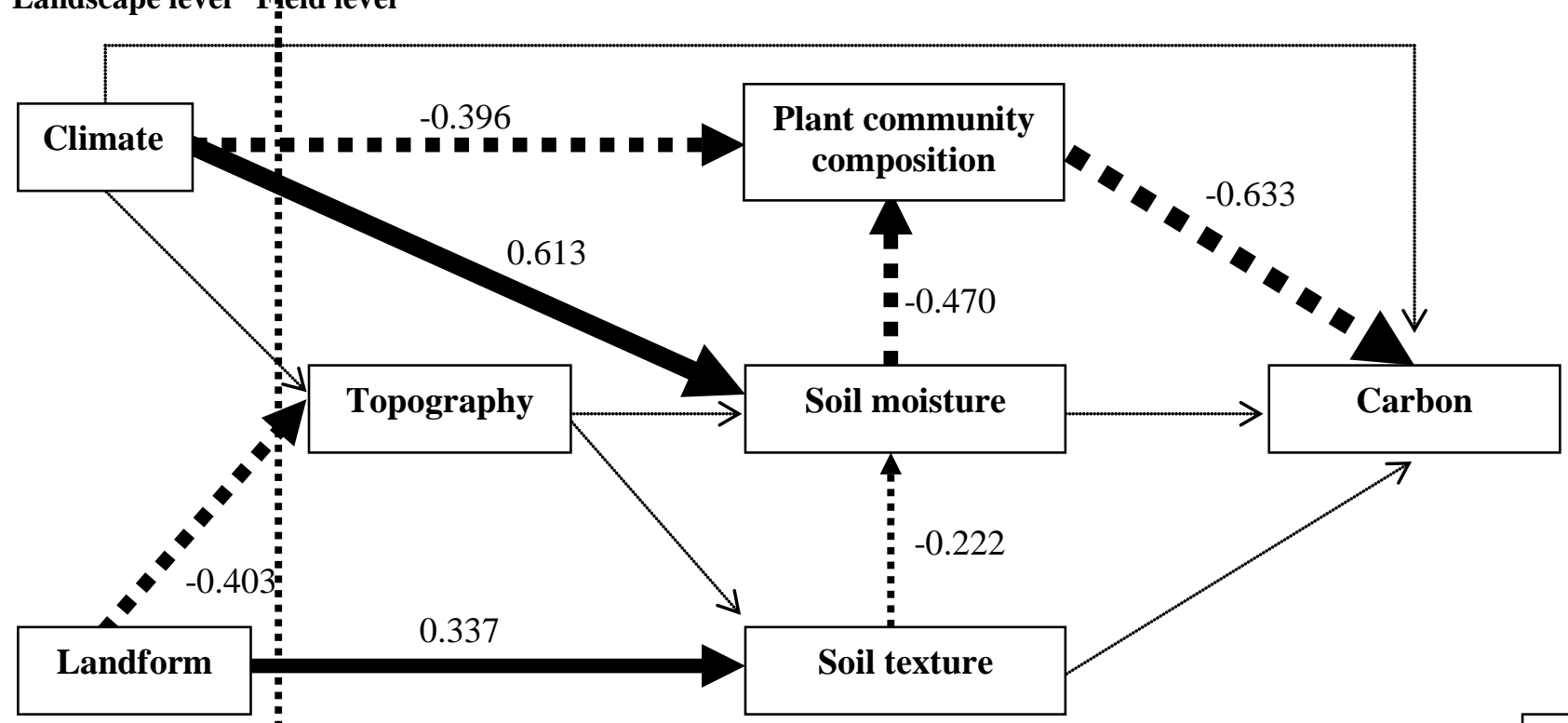

